\title{
Assessment of heavy metal contamination levels of street dust in the city of Lublin, E Poland
}

\author{
Wojciech Zgłobicki ${ }^{1}$ (1) $\cdot$ Małgorzata Telecka ${ }^{1} \cdot$ Sebastian Skupiński ${ }^{1} \cdot$ Aneta Pasierbińska $^{1} \cdot$ Marcin Kozieł $^{1}$
}

Received: 5 May 2018 / Accepted: 17 November 2018 / Published online: 24 November 2018

(c) The Author(s) 2018

\begin{abstract}
Heavy metals are constantly emitted into the environment and pose a major threat to human health, particularly in urban areas. The threat is linked to the presence of $\mathrm{Cd}, \mathrm{Cr}, \mathrm{Cu}, \mathrm{Ni}, \mathrm{Pb}$, and $\mathrm{Zn}$ in street dust, which consists of mineral and organic particles originating from the soil, industrial emitters, motor vehicles, and fuel consumption. The study objective was to determine the level of street dust contamination with trace metals in Lublin and to indicate their potential sources of origin. The analyses were carried out with an energy-dispersive X-ray fluorescence spectrometer. The sampling sites (49) were located within the city streets characterised by varying intensity of motor traffic. The following mean content values and their variation (SD) were determined: Cd: $5.1 \pm 1.7 \mathrm{mg} \mathrm{kg}^{-1}$, Cr: $86.4 \pm 23.3 \mathrm{mg} \mathrm{kg}^{-1}, \mathrm{Cu}: 81.6 \pm 69.2 \mathrm{mg} \mathrm{kg}^{-1}, \mathrm{Ni}: 16.5 \pm 3.9 \mathrm{mg}$ $\mathrm{kg}^{-1}, \mathrm{~Pb}: 44.1 \pm 16.4 \mathrm{mg} \mathrm{kg}^{-1}$, and $\mathrm{Zn}: 241.1 \pm 94.6 \mathrm{mg} \mathrm{kg}^{-1}$. The level of pollution was assessed with several widely used geochemical indices (geoaccumulation index, enrichment factor, pollution index, index of ecological risk, and potential ecological risk index). For most of the indices, the mean (median) values are arranged in the following manner: $\mathrm{Zn}>\mathrm{Cu}($ or $\mathrm{Cd})>\mathrm{Pb}>\mathrm{Ni}>\mathrm{Cr}$. In general, street dust in Lublin does not show pollution with $\mathrm{Cr}, \mathrm{Ni}$, and $\mathrm{Pb}$. $I_{\text {geo }}$ and $\mathrm{EF}$ indices show moderate levels for $\mathrm{Cu}, \mathrm{Cd}$, and $\mathrm{Zn}$; their presence in street dust is linked with anthropogenic factors (motor traffic). A significant threat is posed by $\mathrm{Cd}$, and more than half of the samples show considerable pollution with cadmium (median for the index of ecological risk: 151). The spatial pattern of indices and the results of statistical analyses (CA, PCA) indicate three groups of elements: (1) $\mathrm{Cr}$ and $\mathrm{Ni}$ : natural origin; (2) $\mathrm{Pb}$ : mixed origin; and (3) $\mathrm{Cd}, \mathrm{Cu}$, and $\mathrm{Zn}$ : anthropogenic origin (mainly motor vehicle traffic). Higher content values for metals of anthropogenic origin in street dust indicate that it is a source of pollution of soil and air in the city.
\end{abstract}

Keywords Heavy metals $\cdot$ Pollution indices $\cdot$ Street dust

\section{Introduction}

Street dust is a major source of air and soil contamination in cities (Charlesworth et al. 2011). It consists of mineral and organic particles accumulating on the surface of roads and originating from industrial emitters, motor traffic, and natural sources. In Poland, mineral material and chemical compounds originating from the sand used to keep the roads clear in winter constitute a considerable part of street dust as well. Thus, the main components of street dust are common minerals such as quartz or feldspars. It also contains

Wojciech Zgłobicki

wojciech.zglobicki@umcs.pl

1 Faculty of Earth Sciences and Spatial Management, Maria Curie-Sklodowska University, Kraśnicka 2cd, 20-718 Lublin, Poland various kinds of toxic compounds, including heavy metals. Their main sources are car exhaust emission and the wear and tear of various vehicle parts (tyres, brake discs) (Bilos et al. 2001; Manno et al. 2006; Lu et al. 2010). Pollutants accumulating in street dust are exceptionally hazardous due to the possibility of their secondary emission and occurrence at low height, in the living zone of humans, plants, and animals. Heavy metals can thus penetrate into the human body and pose a grave threat to human health (Aeolian et al. 2008; Zheng et al. 2010; Charlesworth et al. 2011).

In the past, increased lead content was observed in the soils on the sides of roads with high traffic intensity. Other metals also occur here: zinc, cadmium, chromium, nickel, and vanadium. Lead is removed from the atmosphere by the rain and snow (Charlesworth et al. 2011). Alongside lead from fuel consumption, increased concentrations of cadmium, cooper, and zinc occur in roadside soils (De Miguel 
et al. 1997). These metals originate from emissions related to motor traffic and dust produced by the wear and tear of car tyres (zinc oxide is added to rubber during vulcanization). The main source of soil pollution with chromium is its emissions into the atmosphere as a result of coal burning and chrome steel manufacturing (Amato et al. 2011).

Investigations conducted in many cities indicate increased concentrations of trace elements in street dust (e.g., Ahmed and Ishiga 2006; Han et al. 2006; Shi and Wing 2013). It should be stressed that such studies are usually conducted in large and very large cities characterised by a considerable intensity of motor traffic (e.g., Du et al. 2013; Li and Liu 2001; Sezgin et al. 2003; Zhao et al. 2015).

Pollution of street dust with heavy metals is not discussed particularly often in Poland. Few studies on trace-element content in street dust have been published so far (e.g., Walczak 2010; Piontek et al. 2012; Kozanecka et al. 2003). The contamination of soils in the vicinity of transport routes has been discussed much more frequently (e.g., Czarnowska et al. 2002; Klimowicz and Melke 2000; Pasieczna 2003; Plak et al. 2010). No studies have been undertaken so far with regard to a comprehensive index-based assessment of street dust pollution with heavy metals in cities.

Soils in the city of Lublin were studied in the past and the results do not show considerable levels of pollution with heavy metals (Pasieczna 2003; Plak et al. 2010). The same applies to the pollution levels in water sediments (Zgłobicki et al. 2011). However, heavy metals in Lublin's street dust washed away during rainfall and snowmelt accumulate in water sediments in the Bystrzyca river valley downstream of the city (Zgłobicki et al. 2016). This primarily concerns $\mathrm{Cd}$, whose higher levels had already been found in the valley before (Bojakowska and Sokołowska 1996).

The study objective was to assess the level of street dust pollution with heavy metals $(\mathrm{Cd}, \mathrm{Cr}, \mathrm{Cu}, \mathrm{Ni}, \mathrm{Pb}$, and $\mathrm{Zn})$ and to determine the role of human impact on the spatial variation of pollution in Lublin, a medium-sized city located in E Poland. The study will make it possible to estimate the occurrence of pollution threatening residents' health also in medium-sized cities as well as the reason for it. It is the fist study of this kind in Poland. The metals chosen for analysis are commonly regarded as indices of air pollution linked to motor vehicle traffic and industrial emissions in urban areas (De Miguel et al. 1997; Kabata-Pendias and Pendias 1997; Charlesworth et al. 2011).

\section{Materials and methods}

\section{Study area}

Lublin is located in eastern Poland $\left(51^{\circ} 08^{\prime} 23.31^{\prime \prime}-51^{\circ} 17^{\prime} 47.61^{\prime \prime} \mathrm{N}, 22^{\circ} 27^{\prime} 15.41^{\prime \prime}-22^{\circ} 40^{\prime} 24.75^{\prime \prime} \mathrm{E}\right)$

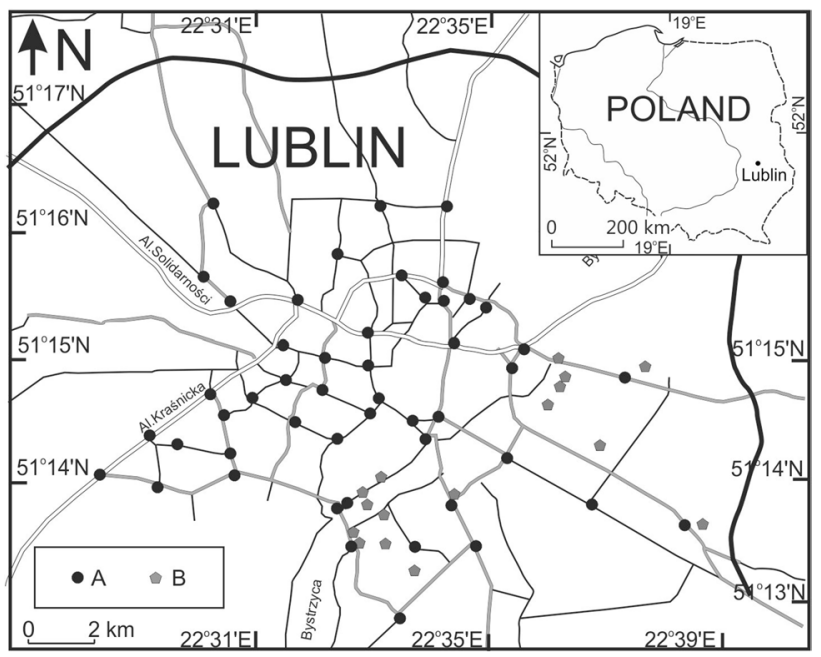

Fig. 1 Location of Lublin. 1-sampling sites, 2-small and medium industrial plants

(Fig. 1). It covers an area of $147.5 \mathrm{~km}^{2}$, inhabited by nearly 350 thousand people. Most industrial areas are located in the eastern part of the city. Major industrial facilities include the Lublin-Wrotków heat and power generating plant, URSUS factory and Sipma agricultural machine factory. Numerous food industry plants as well as pharmaceutical, chemical, and construction enterprises operate here as well.

The physical geography of the city is varied. The western part is characterised by a varied land relief associated with the loess cover. A dense network of deep, dry valleys connected with larger, permanently drained valleys occurs here, and the elevation differences reach $40 \mathrm{~m}$. In the other parts of the city, the differences are much smaller (up to a dozen or so metres). The river system of Lublin consists of Bystrzyca and its tributaries: left hand-Czechówka (flowing west to east) and right hand-Czerniejówka (flowing south to north). These are medium-length rivers $(20-70 \mathrm{~km})$. The mean annual temperature in Lublin is $+8.0^{\circ} \mathrm{C}$. The mean annual precipitation volume is approx. $650 \mathrm{~mm}$. The mean wind speed in Lublin is not high: $2.7 \mathrm{~m} \mathrm{~s}^{-1}$. There is a clear predominance of southerly and westerly winds $(\mathrm{S}, \mathrm{SW}$, W). The dominant soil types are Luvisols and Cambisols developed on loess in the western part of the city; alluvial soils in the Bystrzyca valley as well as Cambisols and podzolic soils in the eastern part.

\section{Data collection}

In the study, the levels of heavy metals $(\mathrm{Cd}, \mathrm{Cr}, \mathrm{Cu}, \mathrm{Ni}, \mathrm{Pb}$, and $\mathrm{Zn}$ ) were analysed in the street dust sampled along roadways in Lublin. The concentration of reference elements $\mathrm{Mn}$ and $\mathrm{Fe}$ was also determined. Samples were collected from a total of 49 points located within the main roads characterised 
by varying intensity of motor traffic. Most of them were situated in the immediate vicinity of junctions, i.e., in locations with increased exhaust emission.

The study material originated from the surface of streets and was sampled in places of dust accumulation along the edges of streets. Samples were collected once, in March 2014. They were collected by sweeping up $500 \mathrm{~g}$ of material with a polyethylene brush and dustpan into plastic bags, then dried at room temperature and put through a $100 \mu \mathrm{m}$ sieve. The preparations for analysis were done in the form of tablets of pressed material (10 g sample and $1 \mathrm{~g}$ wax) ground in a zirconia ball mill (Micro Mill). The analyses were carried out with an energy-dispersive X-ray fluorescence spectrometer (EDXRF, Epsilon5 Panalytical). Each sample was analysed three times, and metal content was calculated as the mean of three measurements. The accuracy of determinations was verified using reference material NCS DC 73385 (five measurements) with certified content of the elements studied: $\mathrm{Cd}=2 \mathrm{mg}$ $\mathrm{kg}^{-1}, \mathrm{Cr}=370 \mathrm{mg} \mathrm{kg}^{-1}, \mathrm{Cu}=40 \mathrm{mg} \mathrm{kg}^{-1}, \mathrm{Ni}=64 \mathrm{mg} \mathrm{kg}^{-1}$, $\mathrm{Pb}=58 \mathrm{mg} \mathrm{kg}^{-1}$, and $\mathrm{Zn}=210 \mathrm{mg} \mathrm{kg}^{-1}$. Measurement error $3-5 \%$. The range of measured values: $\mathrm{Cd}-1.9-2.08 \mathrm{mg}$ $\mathrm{kg}^{-1}, \mathrm{Cr}-342.3-351.3 \mathrm{mg} \mathrm{kg}^{-1}, \mathrm{Cu}-39.7-4.8 \mathrm{mg} \mathrm{kg}^{-1}$, $\mathrm{Ni}-60.1-64.9 \mathrm{mg} \mathrm{kg}^{-1}, \mathrm{~Pb}-58.7-59.3 \mathrm{mg} \mathrm{kg}^{-1}$, and $\mathrm{Zn}-213.6-218.6 \mathrm{mg} \mathrm{kg}^{-1}$.

Road traffic intensity data were available for some of these sampling sites. Based on this data as well as information on the distribution of industrial plants, road parameters (number of lanes and presence of junctions), the sampling sites were divided into four categories: (1) side streets; (2) main streets of the city; (3) main exit roads; and (4) roads in the industrial district.

To determine the geochemical background, the material originating from the soils (parent material) in unpolluted agricultural areas surrounding the city was also analysed. The chemical composition of ten soil samples was determined. This enabled the identification of natural heavy metal levels in the vicinity of Lublin by means of the same method of concentration measurement. Sampling sites are located a few kilometres (about $5 \mathrm{~km}$ ) from the borders of the city.

\section{Environmental pollution indices}

Based on the data obtained, the indices (commonly used in literature) showing the degree of environmental pollution with heavy metals and the related threats were calculated: geoaccumulation index $\left(I_{\text {geo }}\right)$, enrichment factor $(E F)$, pollution index (Pi), index of ecological risk $\left(\mathrm{Er}_{\mathrm{i}}\right)$, and potential ecological risk index (RI) (Müller 1979; Håkanson 1980; Ergin et al. 1991). To identify groups of elements differing in terms of their origin, the following statistical methods were used: correlation analysis, principal component analysis (PCA), and cluster analysis (CA).

The geoaccumulation index is defined by the following formula:
$I_{\text {geo }}=\log _{2}\left(C_{n} / 1.5 C_{\text {ref }}\right)$,

where $C_{n}$ denotes the concentration of the metal, and $C_{\text {ref }}$ denotes the value of the background. Six categories of pollution are distinguished (Müller 1979): unpolluted $\left(I_{\mathrm{geo}}<0\right)$, unpolluted to moderately polluted $\left(I_{\text {geo }}=0-1\right)$, moderately polluted $\left(I_{\text {geo }}=1-2\right)$, moderately to strongly polluted $\left(I_{\text {geo }}=2-3\right)$, highly polluted $\left(I_{\text {geo }}=3-4\right)$, highly to extremely polluted $\left(I_{\mathrm{geo}}=4-5\right)$, and extremely polluted $\left(I_{\mathrm{geo}}>5\right)$.

Enrichment factor is calculated with the following formula:

$\mathrm{EF}=\frac{C_{n} / C_{\mathrm{ref}}}{B_{n} / B_{\text {ref }}}$,

where $C_{n}$ is the metal concentration in a sample, $C_{\text {ref }}$ is the background value for the metal under study, and $B_{n}$ is the reference metal concentration in the sample. In this study, $\mathrm{Mn}$ was used as a reference element. $B_{\text {ref }}$ is the background value for the reference metal. Five categories of pollution are distinguished (Ergin et al. 1991): minimal $(\mathrm{EF}<2)$, moderate $(\mathrm{EF}=2-5)$, significant $(\mathrm{EF}=5-20)$, very high $(E F=20-40)$, and extreme $(E F>40)$.

Pollution index $(\mathrm{Pi})$ can be defined with the following formula:

$\mathrm{Pi}=\frac{C_{n}}{C_{\text {ref }}}$.

See the explanation of the indices above; pollution categories after Shi and Wang (2013): unpolluted $(\mathrm{Pi}<1)$, low pollution $(\mathrm{Pi}=1-2)$, moderate pollution $(\mathrm{Pi}=2-3)$, and high pollution $(\mathrm{Pi}>3)$.

The index of ecological risk factor is defined with the following formula:

$\mathrm{Er}_{\mathrm{i}}=T_{\mathrm{i}} \times \frac{C_{n}}{C_{\text {ref }}}$,

where $T_{1}$ is the toxic-response factor for the metal. The particular metals show varying degrees of toxicity to humans. Håkanson (1980) provides the following values for this index: $\mathrm{Cd}-30, \mathrm{Cr}-2, \mathrm{Cu}-5, \mathrm{Ni}-5, \mathrm{~Pb}-5$, and $\mathrm{Zn}-1$. Five categories of pollution are distinguished: low $(<40)$, moderate $\left(\mathrm{Er}_{\mathrm{i}}=40-80\right)$, considerable $\left(\mathrm{Er}_{\mathrm{i}}=80-160\right)$, high $\left(\mathrm{Er}_{\mathrm{i}}=160-320\right)$, and very high $(>320)$.

Potential ecological risk (RI) is defined as the sum of the index of ecological risk factors $\left(\mathrm{Er}_{\mathrm{i}}\right)$ for metals in a given sample (Soliman et al. 2015). Four categories of the index are distinguished (Håkanson 1980): low $(\mathrm{RI}<150)$, moderate $(R I=150-300)$, considerable $(R I=300-600)$, and high $(\mathrm{RI}>600)$. 


\section{Data analysis}

To identify the origin of the elements, statistical methods were used that enabled to assign the studied elements into groups characterised by similar spatial variation patterns. The investigations included the content of $\mathrm{Fe}$ and Mn which show a slight enrichment in relation with the geochemical background. The following methods were used in data analysis: (1) Pearson's correlation coefficient analysis; (2) principal component analysis (PCA); and (3) cluster analysis (CA). The data for all types of analyses were normalised to the geochemical background values. The normalisation of this kind was necessary, because the natural content of elements varies a lot. Thanks to normalisation, it was possible to avoid the distortion of the results by elements with a high natural content in the soil.

PCA makes it possible to analyse a data set for mutual relationships and generate substitute parameters, i.e., the principal components. The principal components consist of groups of several mutually correlated elements, which reduces the number of independent variables, making it easier to analyse them. The relationships between data are mathematical, but they allow for several practical conclusions. For instance, it can be supposed that the mutually correlated elements constitute a group of elements with a similar origin.

CA enables the determination of geometric, multidimensional Euclidean distances between the specific elements. Thus, the results can confirm the PCA results, but they can also yield additional, multidimensional information on the mutual relationships of data. The distances between data points were analysed using Ward's method.

\section{Results}

\section{Heavy metal content in street dust}

For most of the sites under study, the motor traffic intensity ranges from 50 to 1500 cars per hour (Fig. 2). Mean heavy metal levels in street dust can be arranged in the following order: $\mathrm{Zn}>\mathrm{Cr}>\mathrm{Cu}>\mathrm{Pb}>\mathrm{Ni}>\mathrm{Cd}$. In the case of maximum concentration levels, the order is the same. Mean concentrations, normalised to the background values, are in the following order: $\mathrm{Zn}>\mathrm{Cu}>\mathrm{Cd}>\mathrm{Pb}>\mathrm{Ni}>\mathrm{Cr}>\mathrm{Mn}>\mathrm{F}$ e. The geochemical background was exceeded most in the case of $\mathrm{Cd}, \mathrm{Cu}$, and $\mathrm{Zn}$ (5-6 times on average), while the mean levels of $\mathrm{Cr}, \mathrm{Ni}$, and $\mathrm{Pb}$ were about twice as high as the geochemical background (Table 6). In the case of maximum concentrations, the index was: $\mathrm{Cd}-14, \mathrm{Cr}-6.7, \mathrm{Cu}-31$, $\mathrm{Ni}-2.5, \mathrm{~Pb}-6.7$, and $\mathrm{Zn}-14.9$. A high variation of the content of the studied metals in street dust was found. The variation was the highest for $\mathrm{Cu}(\mathrm{VC}>50$, a high level of

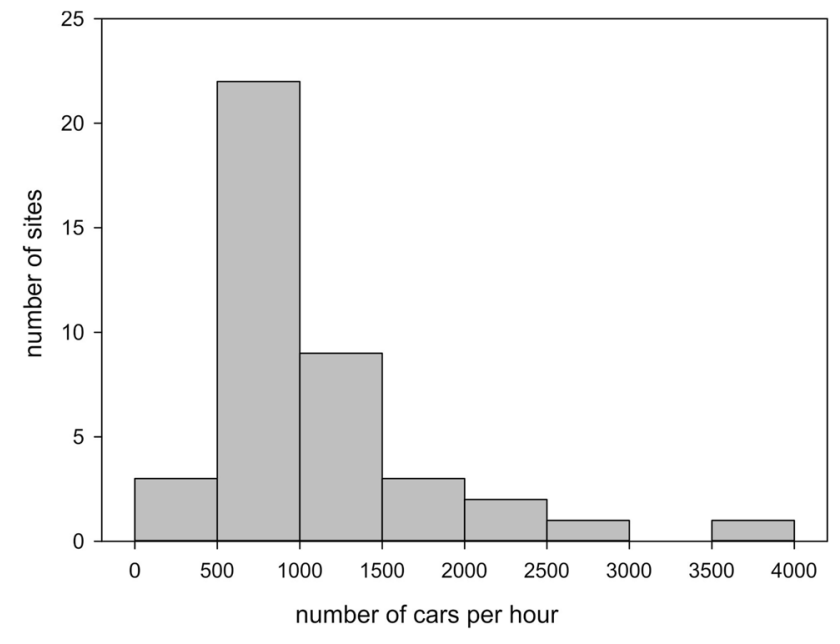

Fig. 2 Intensity of road traffic in selected sampling sites

Table 1 Content of heavy metals in road dust in Lublin $\left(\mathrm{mg} \mathrm{kg}^{-1}\right)$

\begin{tabular}{lclc}
$\begin{array}{l}\text { Mean value } \\
( \pm \mathrm{SD})\end{array}$ & Range & $\begin{array}{l}\text { Variation coef- } \\
\text { ficient }(\mathrm{VC}) \\
(\%)\end{array}$ & $\begin{array}{l}\text { Geochemical } \\
\text { background }\end{array}$ \\
\hline $5.1 \pm 1.7$ & $3.0-14.1$ & 33 & 1.0 \\
$86.4 \pm 23.3$ & $35.1-175.2$ & 26 & 50.0 \\
$81.6 \pm 69.2$ & $21.6-496.7$ & 78 & 16.5 \\
$16.5 \pm 3.9$ & $1.4-23.9$ & 22 & 9.5 \\
$44.1 \pm 16.4$ & $21.5-131.2$ & 36 & 19.6 \\
$241.1 \pm 34$ & $73.3-589$ & 34 & 39.4 \\
\hline
\end{tabular}

variation), clearly lower for $\mathrm{Cd}, \mathrm{Pb}$, and $\mathrm{Zn}(20<\mathrm{VC}<40$, a medium level of variation), and the lowest for $\mathrm{Cr}$ and $\mathrm{Ni}$ (Table 1). The higher the VC value, the higher the anthropogenic impact (Martin et al. 2006).

The lowest heavy metal content levels occur in samples collected from the side streets; they are slightly higher in the case of the main roads, and the highest for exit roads from the city (particularly $\mathrm{Cd}, \mathrm{Cr}$, and $\mathrm{Cu}$ contents) and roads in the industrial district (where $\mathrm{Ni}, \mathrm{Pb}$, and $\mathrm{Zn}$ show the highest levels) (Table 2). The highest variation was found for $\mathrm{Cu}$, the mean values for the main roads are nearly twice as high as for the side streets. In the case of $\mathrm{Cd}, \mathrm{Pb}$ and $\mathrm{Zn}$, the value of this index was about 1.5. $\mathrm{Cr}$ and $\mathrm{Ni}$ showed the lowest variation of concentration in relation with the location of the sample collection sites. This indicates an intense anthropogenic impact on the content of the particular elements: it is the highest for $\mathrm{Cu}$, and the lowest for $\mathrm{Cr}$ and $\mathrm{Ni}$.

\section{Statistical analysis}

The significance level of the correlation is very high; for most data pairs, it is lower than 0.001 and for the remaining 
Table 2 Spatial variation of metals in road dust in Lublin

\begin{tabular}{llrrrrr}
\hline & $\mathrm{Cd}$ & $\mathrm{Cr}$ & $\mathrm{Cu}$ & $\mathrm{Ni}$ & $\mathrm{Pb}$ & $\mathrm{Zn}$ \\
& \multicolumn{1}{l}{ Mean content (maximum content) $\left(\mathrm{mg} \mathrm{kg}^{-1}\right)$} & & & \\
\hline Side streets & $4.5(5.1)$ & $83.7(124.5)$ & $65.6(144.8)$ & $14.4(22.9)$ & $37.9(50.7)$ & $188.5(290.7)$ \\
Main streets of the city & $4.8(6.0)$ & $83.9(103.6)$ & $88.5(172.6)$ & $17.1(21.7)$ & $43.0(67.1)$ & $250.4(427.9)$ \\
Main exit roads & $6.7(14.1)$ & $94.1(175.2)$ & $130.1(496.8)$ & $17.6(23.7)$ & $46.1(75.9)$ & $291.4(589.2)$ \\
Roads in the industrial district & $5.2(6.6)$ & $97.8(147.6)$ & $80.8(116.1)$ & $18.8(23.9)$ & $59.1(131.2)$ & $293.7(395.8)$ \\
\hline
\end{tabular}

Table 3 Correlation matrix for metal concentrations in road dust samples (Pearson correlation coefficients and $p$ values)

\begin{tabular}{lllllllll}
\hline & $\mathrm{Cd}$ & $\mathrm{Cr}$ & $\mathrm{Cu}$ & $\mathrm{Fe}$ & $\mathrm{Mn}$ & $\mathrm{Ni}$ & $\mathrm{Pb}$ & $\mathrm{Zn}$ \\
\hline $\mathrm{Cd}$ & 1 & 0.649 & 0.887 & 0.813 & 0.673 & 0.494 & 0.357 & 0.722 \\
$\mathrm{Cr}$ & $p<0.001$ & 1 & 0.697 & 0.811 & 0.728 & 0.627 & 0.459 & 0.709 \\
$\mathrm{Cu}$ & $p<0.001$ & $p<0.001$ & 1 & 0.815 & 0.632 & 0.507 & 0.352 & 0.740 \\
$\mathrm{Fe}$ & $p<0.001$ & $p<0.001$ & $p<0.001$ & 1 & 0.918 & 0.856 & 0.559 & 0.898 \\
$\mathrm{Mn}$ & $p<0.001$ & $p<0.001$ & $p<0.001$ & $p<0.001$ & 1 & 0.878 & 0.539 & 0.788 \\
$\mathrm{Ni}$ & $p<0.001$ & $p<0.001$ & $p<0.001$ & $p<0.001$ & $p<0.001$ & 1 & 0.507 & 0.771 \\
$\mathrm{~Pb}$ & $p=0.012$ & $p=0.001$ & $p=0.013$ & $p<0.001$ & $p<0.001$ & $p<0.001$ & 1 & 0.606 \\
$\mathrm{Zn}$ & $p<0.001$ & $p<0.001$ & $p<0.001$ & $p<0.001$ & $p<0.001$ & $p<0.001$ & $p<0.001$ & 1 \\
\hline
\end{tabular}

Table 4 Three principal components and eigenvectors influencing them

\begin{tabular}{lccr}
\hline & Factor 1 & Factor 2 & Factor 3 \\
\hline $\mathrm{Cd}$ & $\mathbf{- 0 . 8 2 9}$ & $\mathbf{0 . 4 5 3}$ & -0.152 \\
$\mathrm{Cr}$ & $\mathbf{- 0 . 8 3 9}$ & 0.080 & 0.029 \\
$\mathrm{Cu}$ & $\mathbf{- 0 . 8 3 4}$ & $\mathbf{0 . 4 6 4}$ & -0.156 \\
$\mathrm{Fe}$ & $\mathbf{- 0 . 9 8 6}$ & 0.011 & 0.091 \\
$\mathrm{~Pb}$ & $\mathbf{- 0 . 6 2 2}$ & $\mathbf{- 0 . 5 5 2}$ & $-\mathbf{0 . 5 4 7}$ \\
$\mathrm{Mn}$ & $\mathbf{- 0 . 9 1 1}$ & -0.169 & 0.243 \\
$\mathrm{Ni}$ & $\mathbf{- 0 . 8 3 5}$ & -0.339 & 0.372 \\
$\mathrm{Zn}$ & $\mathbf{- 0 . 9 2 0}$ & -0.064 & -0.054 \\
Variation percentage $(\%)$ & $\mathbf{7 2 . 8 2 2}$ & $\mathbf{1 1 . 0 1 7}$ & $\mathbf{6 . 9 6 9}$ \\
Total variance $(\%)$ & $\mathbf{7 2 . 8 2 2}$ & $\mathbf{8 3 . 8 4}$ & $\mathbf{9 0 . 8 1}$ \\
\hline
\end{tabular}

Bold values indicate statistically important impact $(0.0-0.2-$ no impact; 0.2-0.4-low impact; 0.4-0.7—moderate impact; 0.7-0.9strong impact; $0.9-1.0$ — very strong impact)

data is lower than 0.05 (Table 3). In this case, the correlations of $\mathrm{Pb}$ content with other data content levels are weak or medium. $\mathrm{Fe}$ and $\mathrm{Zn}$ show high correlations with all elements (except $\mathrm{Pb}$ ). Mn correlates with $\mathrm{Cr}, \mathrm{Fe}, \mathrm{Ni}$, and $\mathrm{Zn}$. Strong correlations also occur between $\mathrm{Cu}$ and $\mathrm{Cd}, \mathrm{Fe}$, and $\mathrm{Zn}$ as well as between $\mathrm{Ni}$ and $\mathrm{Fe}, \mathrm{Mn}$, and $\mathrm{Zn}$. On this basis, it is possible to distinguish the following groups of elements between which correlations occur: (1) $\mathrm{Cu}$ and $\mathrm{Cd}$; (2) $\mathrm{Pb}$; and (3) $\mathrm{Cr}, \mathrm{Fe}, \mathrm{Mn}, \mathrm{Ni}$, and $\mathrm{Zn}$.

Table 4 shows a fragment of the matrix of eigenvectors and presents PCA results: three principal components jointly accounting for more than $90 \%$ of the variance, influence of eigenvectors on each of the principal components, percentage of variance explained by each of the first three principal components, and total variance explained by the principal components. Component 1 accounting for $72.8 \%$ of the total variance, having high loadings on the all metals, indicates the impact of natural and anthropogenic sources. It seems, however, that the main role is played by the delivery related to the deposition of soil dust and mineral material used to keep the roads clear in winter. Component 2 explains $11.0 \%$ of the variance, which had high loadings on $\mathrm{Cu}$ and $\mathrm{Cd}$. These metals are related to vehicle emissions. Factor 3 accounts for $6.9 \%$ of the total variance and presents high loadings on $\mathrm{Pb}$, and its delivery is related to anthropogenic and natural impact.

Based on PCA, four groups can be distinguished and treated as elements with a similar origin: anthropogenic, natural, or mixed. The first group consists of $\mathrm{Cr}, \mathrm{Ni}, \mathrm{Zn}$, $\mathrm{Cr}, \mathrm{Mn}$, and $\mathrm{Fe}$, and it can be regarded as a natural group. $\mathrm{Cu}$ and $\mathrm{Cd}$ belong to the second group, and $\mathrm{Pb}$ to the third group. The analysis of further principal components (fifth) shows that $\mathrm{Zn}$ can be assigned to a separate group.

The results of the cluster analysis yield a slightly different image than the PCA: they indicate the existence of two main group of metals probably originating from different sources (Fig. 3). The first group consists of $\mathrm{Cr}, \mathrm{Ni}$, and $\mathrm{Mn}$ as well as $\mathrm{Fe}$ and $\mathrm{Pb}$. The origin of these elements in street dust can be linked mainly with natural factors; the human impact seems to increase in the following order: $(\mathrm{Mn}, \mathrm{Cr}, \mathrm{Ni})<\mathrm{Fe}<\mathrm{Pb}$. The second group consists of elements, whose delivery to street dust is of anthropogenic origin. The greatest delivery occurs for $\mathrm{Cu}$ that forms a separate sub-group. 


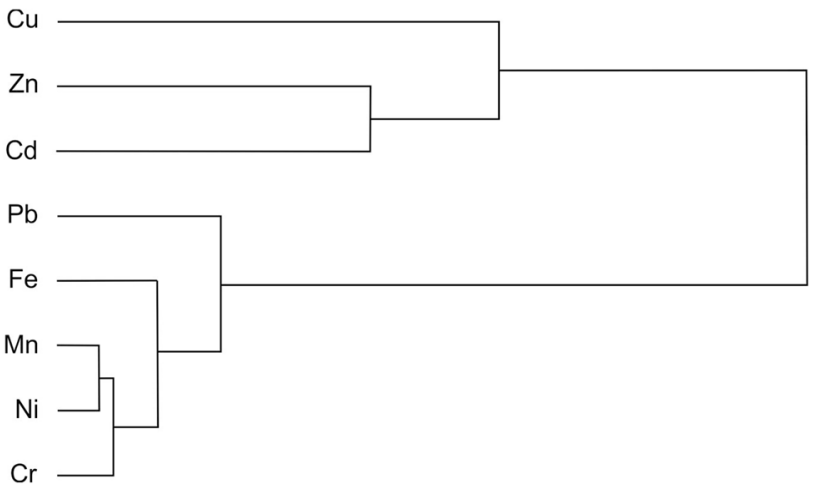

Fig. 3 Results of cluster analysis, using Ward's method, for data normalised to the background values

The statistical analyses used (PCA, CA and data correlation) as well as the relationships between concentrations with the geochemical background showed that the analysed elements form distinct groups that can be interpreted as groups with a different origin of the analysed elements. The results of the methods used partially confirm one another. Based on the analyses, two groups can be distinguished: (a) $\mathrm{Cr}, \mathrm{Mn}, \mathrm{Ni}$, and $\mathrm{Fe}$ : group of elements of natural origin and (b) $\mathrm{Cu}$ and $\mathrm{Cd}$ : elements of anthropogenic origin. In the case of $\mathrm{Pb}$ and $\mathrm{Zn}$, their assignment to a specific group, based on the results of the analyses above, is not unequivocal. This is most probably a result of the fact that the origin of $\mathrm{Pb}$ is linked with natural factors (as indicated by data deviation from the geochemical background of this element), the origin of $\mathrm{Zn}$ is anthropogenic, while the origin of the other elements is largely (though less than in the case of $\mathrm{Pb}$ and $\mathrm{Zn}$ ) anthropogenic or natural.

\section{Pollution indexes}

The geoaccumulation index showed considerable spatial diversity (Fig. 4). In the case of Cd, most of the samples belonged to the moderately polluted category, while samples obtained from the exit roads from the city belonged to the moderately to strongly polluted category $(2.1-2.5)$. In the case of $\mathrm{Cr}$ and $\mathrm{Ni}$, the street dust samples were not polluted or belonged to the unpolluted to moderately polluted category (0.1-0.9). A high variation occurred in the case of $\mathrm{Cu}$ : most dust samples belonged to the moderately polluted category, but some samples also belonged to the unpolluted as well as highly to extremely polluted category (maximum level: 4.3). The index reached the highest level along the main exit road and in the city centre. In the case of $\mathrm{Pb}$, all dust samples except for one belonged to the unpolluted to moderately polluted category (0.05-0.98). Quite a significant spatial variation of the geoaccumulation index occurred also for $\mathrm{Zn}$ : most samples belonged to the moderately to strongly polluted category (2.08-2.85), and 14 to the moderately polluted category (Table 5).

The pollution index shows relatively high levels of pollution with the studied elements. The samples are characterised by a high level of pollution with $\mathrm{Cd}, \mathrm{Cu}$, and $\mathrm{Zn}$, moderate and low pollution with $\mathrm{Pb}$ as well as low and moderate pollution with $\mathrm{Cr}$ and $\mathrm{Ni}$ (Table 5).

All $\mathrm{Cr}, \mathrm{Ni}$, and $\mathrm{Pb}$ samples were characterised by a minimum level of enrichment $(\mathrm{EF}<2)$ (Fig. 4; Table 5). In the case of $\mathrm{Pb}$, one sample, collected in the industrial district, showed a moderate level of enrichment. For $\mathrm{Cd}, \mathrm{Cu}$, and $\mathrm{Zn}$, the enrichment factors were higher and usually ranged between 2 and 5 (moderate). At nine sites located in the eastern part of the city (the industrial district), $\mathrm{Zn}$ had a considerable level of enrichment (5.02-6.45). This factor reached a slightly higher level for $\mathrm{Cu}$ in the same sample (12.9). A considerable level of enrichment for $\mathrm{Cu}$ occurred in four samples collected in a major thoroughfare with a high intensity of trolleybus traffic. A minimum enrichment with this element (1.59-1.93) was found in the northern part of the city. Maximum levels above $3(\mathrm{Cd}, \mathrm{Cu}, \mathrm{Pb}$ i $\mathrm{Zn})$ indicate anthropogenic pollution (Han et al. 2006).

Low levels $(<40)$ of the potential ecological risk index for $\mathrm{Cr}, \mathrm{Ni}, \mathrm{Pb}$, and $\mathrm{Zn}$ were found in all samples. In the case of $\mathrm{Cu}$, the occurrence of moderate risk was found in six samples and high risk (15.5) in one sample. These samples were collected along one of the main thoroughfares. This index reached the highest levels for $\mathrm{Cd}$; it was higher than 150 for more than half of the investigated locations, and the levels were in the high category (161-252) in 18 samples. The highest level (423) found in one sample places the sample in the very high potential ecological risk category (Fig. 4). A vast majority of samples with the highest levels of this index were located within thoroughfares with a high intensity of traffic, including heavy vehicle traffic (Table 5).

Most of the studied samples belong to the moderate potential ecological risk category (total index for all metals). At four locations, i.e., streets with a low intensity of traffic, the low category occurred (111-149). Considerable potential ecological risk was determined (304-352) at three locations along the main thoroughfare of the city. The highest level of this index was 626 (high potential ecological risk) (Fig. 5).

\section{Discussion}

Heavy metal content in street dust and upper soil horizons in cities is originated from various forms of human activity-operation of industrial plants, fuel consumption, exhaust emissions, and the wear of various vehicle parts (AlKhashman 2013; Bilos et al. 2001). Cu is commonly used in vehicle oils (Al-Khashman 2004). It can also be produced as a result of the wear of motor oil pumps, corrosion of metal 

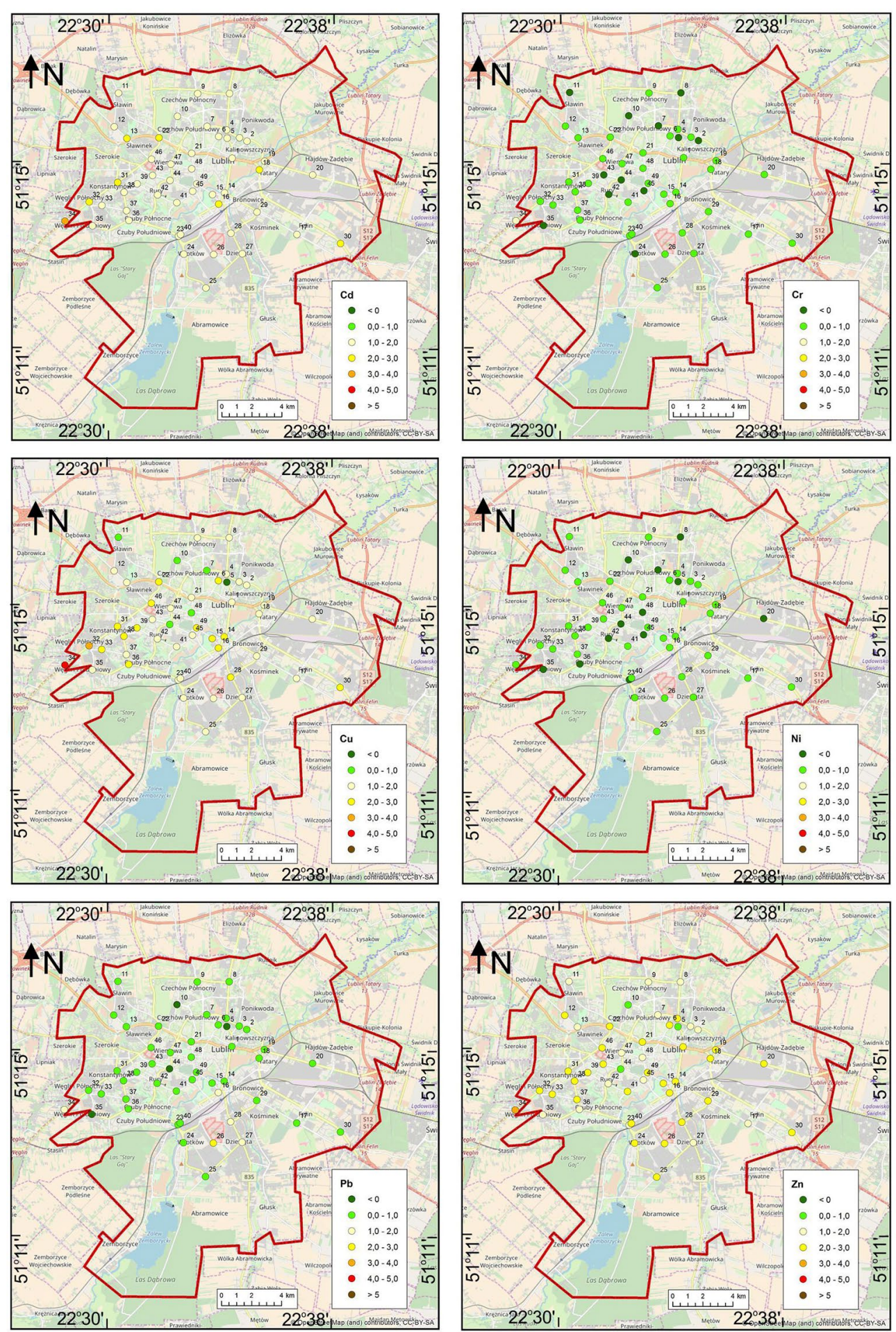

Fig. 4 Spatial diversity of the $I_{\text {geo }}$ index for the heavy metals under study; unpolluted $\left(I_{\text {geo }}<0\right)$, unpolluted to moderately polluted $\left(I_{\text {geo }}=0-1\right)$, moderately polluted $\left(I_{\text {geo }}=1-2\right)$, moderately to strongly

polluted $\left(I_{\text {geo }}=2-3\right)$, highly polluted $\left(I_{\text {geo }}=3-4\right)$, highly to extremely polluted $\left(I_{\mathrm{geo}}=4-5\right)$, and extremely polluted $\left(I_{\mathrm{geo}}>5\right)$

car parts in contact with the oil (De Miguel 1997) as well as engine wear and tear (Al-Khashman 2007; Jaradat and

$\mathrm{Zn}$ is linked to the wear of the moving car parts, for example, tyre wear could be an important source of this metal in street dust (Friedlander 1973; Al-Khashman 2004). Plak 
Table 5 Level of street dust pollution based on pollution indices-mean values (in brackets classes of pollution)
Fig. 5 Spatial diversity variation of the potential ecological risk index: low $(\mathrm{RI}<150)$, moderate $(\mathrm{RI}=150-300)$, considerable $(\mathrm{RI}=300-600)$, and high (RI > 600)

\begin{tabular}{|c|c|c|c|c|c|c|}
\hline & $\mathrm{Cd}$ & $\mathrm{Cr}$ & $\mathrm{Cu}$ & $\mathrm{Ni}$ & $\mathrm{Pb}$ & $\mathrm{Zn}$ \\
\hline \multicolumn{7}{|c|}{ Geoaccumulation index } \\
\hline Min & 1.03 (II) & $-1.09(\mathrm{I})$ & $-0.19(\mathrm{I})$ & $-1.34(\mathrm{I})$ & $-0.43(\mathrm{I})$ & 0.31 (II) \\
\hline Max & $3.23(\mathrm{~V})$ & 1.22 (III) & $4.32(\mathrm{VI})$ & 0.75 (II) & 2.15 (IV) & $3.33(\mathrm{~V})$ \\
\hline Median & 1.75 (III) & 0.21 (II) & 1.84 (II) & 0.28 (I) & $0.60(\mathrm{I})$ & 2.2 (III) \\
\hline \multicolumn{7}{|c|}{ Enrichment factor } \\
\hline Min & $1.87(\mathrm{I})$ & $0.75(\mathrm{I})$ & 1.59 (I) & $0.74(\mathrm{I})$ & $0.96(\mathrm{I})$ & 2.24 (II) \\
\hline Max & 6.08 (III) & $1.72(\mathrm{I})$ & 12.98 (III) & $1.36(\mathrm{I})$ & 3.78 (II) & 6.45 (III) \\
\hline Median & 3.17 (II) & 1.06 (I) & 2.93 (II) & $1.10(\mathrm{I})$ & 1.38 (I) & 3.93 (II) \\
\hline \multicolumn{7}{|c|}{ Pollution index } \\
\hline Min & 3.0 (III) & $0.70(\mathrm{I})$ & 1.31 (II) & 0.59 (I) & 1.22 (II) & 1.86 (II) \\
\hline Max & $14.1(\mathrm{IV})$ & 3.50 (III) & 30.1 (IV) & 2.51 (III) & 3.87 (IV) & 14.95 (IV) \\
\hline Median & $5.05(\mathrm{IV})$ & 1.74 (II) & 5.37 (IV) & 1.83 (II) & 2.27 (III) & 7.03 (IV) \\
\hline \multicolumn{7}{|c|}{ Index of ecological risk } \\
\hline Min & 92.25 (III) & $1.40(\mathrm{I})$ & $6.56(\mathrm{I})$ & 2.95 (I) & $5.55(\mathrm{I})$ & $1.86(\mathrm{I})$ \\
\hline Max & 423.12 (IV) & 7.00 (I) & 150.53 (III) & 12.59 (I) & 33.47 (I) & 14.95 (I) \\
\hline Median & 151.53 (III) & 3.48 (I) & 26.87 (I) & $9.15(\mathrm{I})$ & $11.36(\mathrm{I})$ & 7.03 (I) \\
\hline
\end{tabular}


et al. (2010) also point out that higher $\mathrm{Cu}$ concentrations in the soils in Lublin result from the use of aboveground copper wires powering the trolleybuses. Increased Cd levels in street dust are also linked with road traffic emissions (Divrikli et al. 2005). In the case of Lublin, increased Cd levels in street dust were found within two main thoroughfares (Fig. 4), characterised by high heavy vehicle traffic. Coal-fired furnaces, still used to heat private homes in the city, are another source of $\mathrm{Cd}$. Its increased levels occurred in areas, where this kind of homes predominates. The greatest contamination with $\mathrm{Zn}$ was found in the eastern part of the city, where an automotive factory existed in the past.

The elements described in this study show varying toxicity for humans. Cd is the most toxic element that can be absorbed by the respiratory system and can reside in the human body for a long time. The toxic effect of $\mathrm{Cd}$ consists of kidney dysfunction, neoplastic transformations, and hypertension. The toxicity of $\mathrm{Cu}, \mathrm{Ni}$, and $\mathrm{Pb}$ is lower, but humans are susceptible to the bioaccumulation of these elements absorbed into the body through the respiratory system (Kabata-Pendias and Pendias 1999). Increased levels were found only in the case of $\mathrm{Cu}$; hence, this element may pose a threat to residents. Copper leads to oxidative cell damage and causes neuron disorders (Gaetle and Chow 2003).

$\mathrm{Cd}, \mathrm{Cr}, \mathrm{Cu}, \mathrm{Ni}, \mathrm{Pb}$, and $\mathrm{Zn}$ content levels are similar to the levels found in other cities in Europe and North America with a similar population size. Only the mean concentrations for $\mathrm{Cd}$ are clearly higher than in Tallinn or Coventry. In the case of other elements, their content levels are usually lower (Table 6).

The calculated indices show varying levels of street dust pollution. In the case of the geoaccumulation index and pollution index, the mean values follow this order: $\mathrm{Zn}>\mathrm{Cu}>\mathrm{Cd}>\mathrm{Pb}>\mathrm{Ni}>\mathrm{Cr}$. A similar situation occurs in the case of the enrichment factor but the mean index for $\mathrm{Cd}$ is higher than for $\mathrm{Cu}$. Due to the varying toxicity of the studied elements, a distinctly different order occurs in the case of the index of ecological risk: $\mathrm{Cd}>\mathrm{Cu}>\mathrm{Pb}>\mathrm{Ni}>\mathrm{Cr}>\mathrm{Zn}$. Indices such as $I_{\text {geo }}$ and EF indicate a moderate contamination/enrichment of street dust with $\mathrm{Cd}, \mathrm{Cu}$, and $\mathrm{Zn}$. The pollution index for these elements places them in the high pollution category. In the case of the other metals, all indices indicate a lack of pollution or low pollution with $\mathrm{Cr}$, $\mathrm{Ni}$, and $\mathrm{Pb}$. The index of ecological risk shows a considerable level of pollution only for Cd. Similar to other studies, this study did not find increased $\mathrm{Pb}$ levels in street dust (Yeung et al. 2003). In the past, this element was the main pollution index, but owing to the common use of unleaded petrol, exhaust fumes ceased to be the main source of $\mathrm{Pb}$ in the air (De Miguel et al. 1997).

A comparison of the obtained results concerning environmental pollution indices indicates a similar level of pollution even in the case of cities with a distinctly greater population and higher number of industrial plants (AlKhashman 2013; Shi and Wang 2013; Gope et al. 2017; Han and $\mathrm{Lu}$ 2017). The contamination of street dust in Lublin with $\mathrm{Cd}$ is distinctly higher than that reported for cities in the Middle East and China. However, it was not as high as, for example, in Kuala Lumpur, where the maximum EF for $\mathrm{Cd}$ in the $<125 \mu \mathrm{m}$ fraction was 16.5 (Han et. al. 2014). High EF values for $\mathrm{Pb}$ are also reported by $\mathrm{Al}-$ Khashman (2013) for the city of Ma' an (Jordan). It should be stressed, however, that in both cases, the authors used a different method of determining this index: the reference value that they adopted was the content of the element in the Earth's crust, which is distinctly lower than content in reference soils. This shows the difficulty of directly comparing results obtained for various cities. The main challenge here is the method of determining the geochemical background that plays a key role in the case of some pollution indices.

Permissible levels of heavy metal content in street dust have not been established so far, and it is inappropriate to compare the obtained values directly with such standards for soil or air. In general, however, it can be concluded that mean content values are lower than those indicated for agriculturally used soils in Poland: $\mathrm{Cd}-4 \mathrm{~km} \mathrm{~kg}^{-1}, \mathrm{Cr}-150 \mathrm{mg}$ $\mathrm{kg}^{-1}, \mathrm{Cu}-150 \mathrm{mg} \mathrm{kg}^{-1}, \mathrm{Ni}-100 \mathrm{mg} \mathrm{kg}{ }^{-1}, \mathrm{~Pb}-100 \mathrm{mg}$ $\mathrm{kg}^{-1}$, and $\mathrm{Zn}-300 \mathrm{mg} \mathrm{kg}^{-1}$ (Kabata-Pendias and Pendias 1999). It should be remembered, however, that in the case of soils, metals are immobilised to some extent and can be absorbed in the human body mainly through food, i.e., plants that have taken up these metals from the soil. In the case of street dust, on the other hand, heavy metals can be released by air mass movement and absorbed directly by the
Table 6 Heavy metal content in cities around the world

\begin{tabular}{lrlllllll}
\hline Location & Population & $\mathrm{Cd}$ & $\mathrm{Cr}$ & $\mathrm{Cu}$ & $\mathrm{Ni}$ & $\mathrm{Pb}$ & $\mathrm{Zn}$ & Sources \\
\hline Lublin & 350,000 & 5.1 & 86.4 & 81.6 & 16.5 & 44.1 & 241.1 & Present study \\
Warsaw & $1,700,000$ & - & - & 31 & 10 & 34 & 64 & Kazanecka et al. (2003) \\
Zielona Góra & 140,000 & $0.2-9.7$ & - & $12-264$ & - & - & $20-409$ & Walczak (2010) \\
Oslo & 630,000 & 1.4 & - & 123 & 41 & 180 & 412 & De Miguel et al. (1997) \\
Coventry & 300,000 & 0.9 & - & 226 & 130 & 47 & 386 & Charlesworth et al. (2003) \\
Hamilton & 500,000 & 4.0 & - & 129 & - & 214 & 645 & Droppo et al. (1998) \\
\hline
\end{tabular}


respiratory system. Therefore, even lower levels of heavy metals can be harmful.

As it could be expected, street dust is much more polluted with heavy metals than soils in Lublin (Pasieczna 2003). The ratios of their mean content in street dust to their mean content in the city's soils are as follows: $\mathrm{Cd} \mathrm{10:1,} \mathrm{Cr} \mathrm{10:1,} \mathrm{Cu}$ 10:1, $\mathrm{Pb} 3: 1$, and $\mathrm{Zn} 6: 1$. Their higher levels in soils in the vicinity of streets indicate that street dust is the source of this pollution (Plak et al. 2010). The results of research on soils in Torun (N Poland), a city of similar size to Lublin, show a lack of pollution in the case of $I_{\text {geo }}$ and a significant enrichment of $\mathrm{Pb}$ and $\mathrm{Cu}$ in the case of $\mathrm{EF}$ (Charzyński et al. 2017).

As in the case of studies by other authors, no correlation was found between the intensity of motor traffic and heavy metal content (Charlesworth et al. 2011). It should be noted that such data for locations with the highest level of pollution with street dust were not available. Only in the case of $\mathrm{Cu}$, a correlation was identified between its content in street dust and the network of aboveground power cables made of copper. Increased $\mathrm{Cu}$ levels occurred in locations with a high intensity of trolleybus traffic.

Further research is needed on the seasonal variation of the content of the heavy metals, multi-year trends as well as their content in different sizes of dust particles. It should also be remembered that the individual indices show slightly different pollution levels, even though the general trends for the specific elements are maintained in Lublin's street dust. The problem of improving the method of calculating the indices requires further study.

\section{Conclusions}

The level of street dust contamination with heavy metals in Lublin, determined based on five geochemical indices, is generally low. Only the pollution index reaches values indicative of considerable pollution in the case of some elements. Pollution with $\mathrm{Cr}$ and Ni does not occur. Samples are characterised by moderate pollution or a lack of pollution with $\mathrm{Pb}$ and $\mathrm{Zn}$, although increased $\mathrm{Zn}$ levels occurred in some samples. The most significant pollution was found in the case of $\mathrm{Cd}$ and $\mathrm{Cu}$ in some samples. Particularly, for $\mathrm{Cd}$, a highly toxic element, the pollution of street dust in Lublin should be regarded as a major health problem. Heavy metal levels in street dust are distinctly higher in comparison with their levels in the soils in Lublin. Thus, higher levels of elements from this group indicate their anthropogenic source. It should be stressed that the highest concentrations of $\mathrm{Cd}$ occurred within the main thoroughfare of the city. There was a distinct correlation with the presence of trolleybus wires in the case of $\mathrm{Cu}$ and the presence of industrial plants in the case of $\mathrm{Zn}$.
The results of statistical methods (correlations, PCA, and $\mathrm{CA}$ ) and the analysis of the spatial pattern of pollution indicate the possibility of distinguishing the following groups of elements and their origin in street dust: (1) $\mathrm{Fe}, \mathrm{Mn}, \mathrm{Cr}$, $\mathrm{Ni}$, (2) $\mathrm{Pb},(3) \mathrm{Cd}, \mathrm{Cu}$ and $\mathrm{Zn}$. The influence of natural and anthropogenic factors can be identified as a source of heavy metals in the case of group (1). Among these factors, the delivery of mineral material linked with winter road maintenance as well as redeposition of street dust are predominant. In group (2), anthropogenic influences (vehicular emissions) are predominant but natural delivery occurs as well. In group (3), anthropogenic delivery (vehicle emissions, brake linings) is predominant.

Acknowledgements The study was financed with research funds from the Faculty of Earth Sciences and Spatial Management, Maria CurieSklodowska University. The authors wish to thank the anonymous reviewers for their valuable comments and suggestions to improve the quality of this paper.

Open Access This article is distributed under the terms of the Creative Commons Attribution 4.0 International License (http://creativeco mmons.org/licenses/by/4.0/), which permits unrestricted use, distribution, and reproduction in any medium, provided you give appropriate credit to the original author(s) and the source, provide a link to the Creative Commons license, and indicate if changes were made.

\section{References}

Aelion CM, Davis HT, McDermott S, Lawson AB (2008) Metal concentrations in rural topsoil in South Carolina: potential for human health impact. Sci Total Environ 402:149-156

Ahmed F, Ishiga H (2006) Trace metal concentrations in street dusts of Dhaka city, Bangladesh. Atmos Environ 40:3835-3844

Al-Khashman OA (2004) Heavy metal distribution in dust, street dust and soils from the work place in Karak Industrial Estate, Jordan. Atmos Environ 38:6803-6812

Al-Khashman OA (2007) Determination of metal accumulation in deposited street dusts in Amman, Jordan. Environ Geochem Health 29:1-10

Al-Khashman OA (2013) Assessment of heavy metals contamination in deposited dusts in different urbanized areas in the city of Ma an, Jordan. Environ Earth Sci 70:2603-2612

Amato F, Pandolfi M, Moreno T, Furger M, Pey J, Alastuey A, Bukowiecki N, Prevot ASH, Baltensperger U, Querol X (2011) Sources and variability of inhalable street dust particles in three European cities. Atmos Environ 45:6777-6787

Bilos C, Colombo JC, Skorupka CN, Presa MJR (2001) Sources, distribution and variability of airborne trace metals in La Plata City area, Argentina. Environ Pollut 111:149-158

Bojakowska I, Sokołowska G (1996) Heavy metals in the Bystrzyca river flood plain. Geol Q 40(3):467-480

Charlesworth S, Everett M, McCarthy R, Ordonez A, de Miguel E (2003) A comparative study of heavy metal concentration and distribution in deposited street dusts in a large and small urban area: Birmingham and Coventry, West Midlands, UK. Environ Int 29:563-573

Charlesworth S, De Miguel E, Ordonez A (2011) A review of the distribution of particulate trace elements in urban terrestrial 
environments and its application to consideration of risk. Environ Geochem Health 33(2):103-123

Charzyński P, Plak A, Hanaka A (2017) Influence of the soil sealing on the geoaccumulation index of heavy and various pollution factors. Environ Sci Pollut Res 24:4801-4811

Czarnowska K, Chlibiuk M, Kozanecka K (2002) Pierwiastki śladowe w glebach gruntów rolnych przy drogach wokół Warszawy. Roczn Glebozn 53(3-4):67-74

De Miguel E, Llamas JF, Chacon E, Berg T, Larsen S, Royset O, Vadset M (1997) Origin and patterns of distribution of trace elements in street dust: unleadedpetrol and urban lead. Atmos Environ 31:2733-2740

Divrikli V, Soylak M, Elic L, Dogan M (2005) Trace heavy metal in street dust samples from Yozgat City Center, Turkey. J Trace Microprobe 21:351-361

Droppo IG, Irvine KN, Murphy TP, Jaskot C (1998) Fractionated metals in street dust of a mixed land use sewershed, Hamilton, Ontario. Hydrology in a Changing Environment III, pp 383-394

Du Y, Gao B, Zhou H, Ju X, Hao H, Yin S (2013) Health risk assessment of heavy metals in street dusts in urban parks of Beijing, China. Procedia Environ Sci 18:299-309

Ergin M, Saydam C, Basturk O, Erdem E, Yoruk R (1991) Metal concentrations in surface sediments from the two coastal inlets (Golden Horn Estuary and Izmit Bay) of the northeastern Sea of Marmara. Chem Geol 91:269-285

Friedlander SK (1973) Chemical element balances and identification of air pollution sources. Environ Sci Technol 7:235-240

Gaetle LM, Chow CK (2003) Copper toxicity, oxidative stress, and antioxidant nutrients. Toxicology 189:147-163

Gope M, Masto RE, George J, Hoque RR, Balachandran S (2017) Bioavailability and health risk of some potentially toxic elements $(\mathrm{Cd}$, $\mathrm{Cu}, \mathrm{Pb}$ and $\mathrm{Zn}$ ) in street dust of Asansol, India. Ecotox Environ Safe 138:231-241

Håkanson L (1980) An ecological risk index for aquatic pollution control: a sedimentological approach. Water Res 14:975-1001

Han X, Lu X (2017) Spatial distribution, environmental risk and source of heavy metals in street dust from an industrial city in semi-arid area of China. Arch Environ Protect 43(2):10-19

Han YM, Du PX, Cao JJ, Posmentier ES (2006) Multivariate analysis of heavy metal contamination in urban dusts of Xi' an, Central China. Sci Total Environ 355:176-186

Han NMM, Latif MT, Othman M, Dominick D, Mohamad N, Juahir H, Tahir NM (2014) Composition of selected heavy metals in road dust from Kuala Lumpur city centre. Environ Earth Sci 72:849-859

Jaradat Q, Momani K (1999) Contamination of roadside soil, plants and air with heavy metals in Jordan. A comparative study. Turk J Chem 23:209-220

Kabata-Pendias A, Pendias H (1999) Biogeochemia pierwiastków śladowych. Wyd. Nauk. PWN, Warszawa

Klimowicz Z, Melke J (2000) Zawartość metali ciężkich w glebach w sąsiedztwie szlaków komunikacyjnych na przykładzie wybranych tras. Roczn Glebozn 51(3-4):37-46

Kozanecka T, Czarnowska K, Jaworska A (2003) Występowanie metali ciężkich w grubym pyle drogowym wokół Warszawy. Roczniki Gleboznawcze LIV 3:73-78

Li X, Liu PS (2001) Heavy metal contamination of urban soils and street dusts in Hong Kong. Appl Geochem 16:1361-1368
Lu X, Wang L, Li LY, Lei K, Huang L, Kang D (2010) Multivariate statistical analysis of heavy metals in street dust of Baoji, NW China. J Hazard Mater 173:744-749

Manno E, Varrica D, Dongarrà G (2006) Metal distribution in road dust samples collected in an urban area close to a petrochemical plant at Gela, Sicily. Atmos Environ 40(30):5929-5941

Martin JAR, Arias ML, Corbi JMG (2006) Heavy metal contents in agricultural soils in the Ebro basin (Spain). Application of the multivariate geostatistical methods to study spatial variations. Environ Pollut 144:1001-1012

Müller G (1979) Schwermetalle in den Sedimenten des RheinsVeränderungen seit 1971. Umschau 24:778-783

Pasieczna A (2003) Atlas zanieczyszczeń gleb miejskich w Polsce. Państwowy Instytut Geologiczny, Warszawa

Piontek M, Walczak B, Czyżewska W, Lechów H (2012) Miedź, kadm i cynk w pyle drogowym miast oraz określenie toksyczności związków tych metali metodą biologiczną. Kosmos Problemy Nauk Biologicznych 61(3):409-415

Plak A, Bartmiński P, Dębicki R (2010) Influence of public transport on the content of chosen heavy metals in soils neighbouring Lublin streets (in Polish). Proc Ecopole 4(1):167-171

Sezgin N, Ozcan HK, Demir G, Nemlioglu S, Bayat C (2003) Determination of heavy metal concentration in street dusts in Istanbul E-5 highway. Environ Int 29:979-985

Shi X, Wang J (2013) Comparison of different methods for assessing heavy metal contamination in street dust of Xianyang City, NW China. Environ Earth Sci 68:2409-2415

Soliman NF, Nasr SM, Okbah MA (2015) Potential ecological risk of heavy metals in sediments from the Mediterranean coast, Egypt. J Environ Health Sci 13:70

Walczak B (2010) Lead and zinc in the street dust of Zielona Góra Poland. In: Pawłowski L, Dudzińska MR, Pawłowski A (eds) Environmental engineering III. Taylor \& Francis Group, London, pp 105-113

Yeung ZLL, Kwok RCW, Yu KN (2003) Determination of multi-element profiles of street dust using energy dispersive X-ray fluorescence (EDXRF). Appl Radiat Isotopes 58:339-346

Zgłobicki W, Lata L, Plak A, Reszka M (2011) Geochemical and statistical approach to evaluate background concentration of $\mathrm{Cd}$, $\mathrm{Cu}, \mathrm{Pb}$ and $\mathrm{Zn}$ (case study: Eastern Poland). Environ Earth Sci 62:347-355

Zgłobicki W, Telecka M, Skupiński S (2016) Assessment of microscale variation of heavy metal pollution of the Bystrzyca River alluvia downstream from Lublin. Pol J Soil Sci 49(2):167-180

Zhao N, Lu X, Chao S (2015) Multivariate statistical analysis of heavy metals in less than $100 \mu \mathrm{m}$ particles of street dust from Xining, China. Environ Earth Sci 73:2319-2327

Zheng N, Liu J, Wang Q, Liang Z (2010) Health risk assessment of heavy metal exposure to street dust in the zinc smelting district, northeast of China. Sci Total Environ 408:726-733

Publisher's Note Springer Nature remains neutral with regard to jurisdictional claims in published maps and institutional affiliations. 